\title{
PENGETAHUAN MAHASISWA BIOLOGI MENGENAI PENERAPAN BIOTEKNOLOGI REKAYASA GENETIKA DITINJAU DARI PERSPEKTIF ISLAM
}

\author{
Abdul Hadi \\ Institut Pembina Rohani Islam Jakarta (IPRIJA) \\ Email : abdhadi1002@gmail.com
}

\begin{abstract}
Advances in science and technology encourage the economic, industrial, and health sectors to develop rapidly through diagnostic and therapeutic treatments. Therapeutic-based health research encourages the advancement of modern biotechnology to answer all medical problems. However, not infrequently, advances in modern biotechnology are often considered contrary to moral, ethical, social, legal, psychological and religious values. The presence of biotechnology is considered to dominate human life and has great power to change the development of living organisms and creates an interesting condition to study and analyze when it is associated with the management of medical biotechnology products that are safe for the environment, people's lives and religion. This study aims to determine the level of knowledge of Biology students at $\mathrm{X} \& \mathrm{Y}$ universities regarding the application of genetic engineering biotechnology when viewed from an Islamic perspective and the relationship of knowledge to Biology students' attitudes about genetic engineering using qualitative data research through planning (antecedents), processes (transactions), and results (outcomes). The results of the study of 60 biology students from universities $\mathrm{X}$ and $\mathrm{Y}$ obtained 8 students $\mathrm{X}$ and 7 students $\mathrm{Y}$ had knowledge of genetic engineering in an Islamic perspective. Meanwhile, after all students participated in the discussion session and were given articles on genetic engineering in an Islamic perspective, all students agreed that the application of genetic engineering must be based on religious knowledge so that research was carried out in accordance with the rules contained in the MUI fatwa No. 35 of 2013. Therefore, advances in science and technology, especially in genetic engineering, must be accompanied by an open mind and a strong religious understanding so as not to lead to misperceptions of negative things.
\end{abstract}

Keywords : Biotechnology, Science and Technology, Health, Genetic Engineering 


\begin{abstract}
ABSTRAK
Kemajuan IPTEK mendorong sektor ekonomi, industri dan Kesehatan untuk berkembang secara cepat melalui pengobatan secara diagnostik maupun terapeutik. Riset kesehataan berbasis terapeutik mendorong kemajuan bioteknologi modern untuk menjawab segala permasalahan medis. Namun, tidak jarang, kemajuan bioteknologi modern sering kali dianggap bertentangan dengan nilai moral, etika, sosial, hukum, psikologi dan Agama. Kehadiran bioteknologi dianggap menguasai kehidupan manusia dan memiliki kekuatan besar untuk mengubah perkembangan organisme hidup serta menciptakan suatu kondisi yang menarik untuk dikaji serta dianalisa bila dikaitkan dengan pengelolaan produk bioteknologi medis yang aman bagi lingkungan, kehidupan masyarakat serta Agama. Penelitian ini bertujuan untuk mengetahui tingkat pengetahuan mahasiswa Biologi universitas X \& Y mengenai penerapan bioteknologi rekayasa genetika jika ditinjau dari perspektif Islam dan hubungan pengetahuan terhadap sikap mahasiswa Biologi tentang rekayasa genetika menggunakan penelitian data kualitatif melalui perencanaan (antecedents), proses (transactions), dan hasil (outcomes). Hasil penelitian 60 mahasiswa biologi dari universitas $\mathrm{X}$ dan $\mathrm{Y}$ diperoleh 8 mahasiswa $\mathrm{X}$ dan 7 mahasiswa $\mathrm{Y}$ memiliki pengetahuan rekayasa genetika dalam perspektif Islam. Sedangkan, setelah semua mahasiswa mengikuti sesi diskusi serta diberikan artikel mengenai rekayasa genetika dalam perspektif Islam, semua mahasiswa setuju mengenai penerapan rekayasa genetika harus didasari dengan ilmu Agama agar pelaksanaan penelitian dilakukan sesuai dengan aturan-aturan yang termuat dalam fatwa MUI No.35 tahun 2013. Oleh karena itu, kemajuan IPTEK khususnya dalam rekayasa genetika harus diiringi dengan pemikiran terbuka dan pemahaman agama yang kuat agar tidak menimbulkan kesalahan persepsi ke hal negatif.
\end{abstract}

Kata Kunci : Bioteknologi, IPTEK, Kesehatan, Rekayasa Genetika 


\section{PENDAHULUAN \\ Latar Belakang Masalah}

Ilmu pengetahuan dan teknologi (IPTEK) dalam segala sektor semakin lama semakin besar dan kemajuannya pun sangat pesat. Berdasarkan teori Schumpeter, inovasi ilmu pengetahuan dan teknologi diprediksi akan mendorong pertumbuhan ekonomi di segala sektor. Hal tesebut dapat dibuktikan dengan terbangunnya new economy dengan karakter dan pasar yang berbeda dengan ekonomi kontemporer. New economy didukung oleh industri otomotif, baja dan lain-lain. Selain di bidang ekonomi, sektor Kesehatan juga menunjukkan kemajuan yang signifikan. Kemajuan IPTEK khususnya dalam bidang Kesehatan dapat dilihat dari banyaknya penemuan obat-obatan di bidang farmasi maupun terapi pengobatannya ${ }^{1}$. Selain itu, perkembangan IPTEK bidang kesehatan bertumpu pada penelitian melalui percobaan-percobaan yang terus dikembangkan setiap tahunnya. Dalam bidang ilmu kedokteran, penelitian pada manusia merupakan sesuatu yang tidak dapat dihindarkan demi pengembangan pengobatan dalam mendiagnosa, terapi, pencegahan dan pemberantasan penyakit ${ }^{2}$.

Berdasarkan pedoman etik Indonesia ${ }^{3}$, bidang penelitian Kesehatan memiliki dua macam perbedaan penelitian yang dibedakan secara mendasar, yaitu penelitian dengan tujuan utama sebagai diagnostik atau terapeutik bagi pasien. Penelitian ini adalah penelitian riset klinis dimana peneliti berkerjasama dengan perawat profesional untuk mendapatkan hasil penelitian yang maksimal. Kedua, penelitian dengan tujuan utamanya adalah ilmiah murni tanpa nilai diagnostik dan terapeutik bagi subyek yang akan diteliti. Penelitian ini disebut sebagai riset biomedik non-klinis, karena penelitian ini non terapeutik.

Terapeutik sendiri merupakan komunikasi secara langsung secara verbal, ekspresi tubuh dan wajah antara tenaga medis seperti dokter dan paramedis seperti perawat kepada pasien yang berobat di rumah sakit ${ }^{4}$. Menurut Rogers sebagaimana dikutip oleh Effendi, proses komunikasi Islami berbasis komunikasi terapeutik akan menimbulkan relasi yang nyaman antara pasien dengan tenaga medis baik dokter maupun perawat sehingga komunikasi interpersonal atau komunikasi antarpribadi akan efektif kalau suasana yang dibangun bersifat dialogis, saling menaruh hormat dan perhatian satu sama lain, tidak bersikap merendahkan dan menganggap lebih tinggi profesi dokter atau perawat dibandingkan dengan pasien ${ }^{5}$.

Riset biomedik yang diiringi dengan komunikasi terapeutik akan membuat pasien merasa nyaman sehingga pengambilan sampel untuk penelitian pun jadi mudah dilakukan. Lahirnya bioteknologi modern ini ditandai dengan munculnya teknologi Rekombinan DNA (Deoxiribose Nucleic Acid). Teknologi ini bukan hanya memberikan harapan penyempurnaan penelitian-penelitian sebelumnya,

1 Veronica Komalawati, Peranan Informed Consent Dalam Transaksi Terapeutik Suatu Tinjauan Yuridis Persetujuan Dalam Hubungan Dokter dan Pasien, Citra Aditya Bakti, Bandung, 1999, hlm 89-90.

2 Ratna Suprapti Samil, Etika Kedokteran Indonesia, Yayasan Bina Pustaka Sarwono Prawirohardjo, Jakarta, 2001, hlm 121

3 Pedoman Etik Indonesia, 1987: hlm5-12, dalam Veronica Komalawati, Peranan Informed....,Op Cit hlm 89-90

${ }^{4}$ Wijaya, dkk, Komunikasi Terapeutik (Bandung: Akademi Kesehatan Gigi Depkes RI, 2000), h.34.

${ }^{5}$ Onong Uchjana Effendy, Ilmu Komunikasi Teori dan Filsafat Komunikasi (Bandung, PT. Cipta Aditya Bakti, 2000), h.9 
tetapi diharapkan juga mampu mengembangkan produk baru hasil penelitian ${ }^{6}$. Teknik-teknik penelitian diharapkan terus berkembang dari masa ke masa secara bertahap meskipun setiap tahapan yang dilakukan tidak akan lepas dari sikap pro dan kontra. Sikap pro kontra bukan hanya dipermasalahkan dari ilmu pengetahuan itu sendiri, melainkan implikasi dan dampak yang ditimbulkan terhadap manusia dari segi moral, etika, sosial, hukum, psikologi dan Agama.

Setiap penemuan dan pengembangan IPTEK untuk menjawab segala permasalahan medis bagi manusia jarang terlepas dari dilema. Perkembangan penelitian bioteknologi dalam bidang medis dapat menimbulkan keuntungan yang baik dan buruk sehingga terdapat hal mustahil bagi manusia dengan hikmatnya sendiri dapat menjawab setiap permasalahan yang ada dengan memuaskan tanpa menimbulkan ekses-ekses negatif. Manusia hanya dapat menciptakan bioteknologi medis tanpa mampu mengantisipasi dampak bioteknologi medis itu sendiri. Terdapat kasus bioteknologi medis yang menimbulkan gesekan dalam bidang etika, moral, nilai dan hukum serta agama mengenai kasus kloning. Teknik kloning merujuk pada berbagai usaha yang dilakukan manusia untuk mendapatkan salinan berkas DNA atau gen, sel maupun organisme atau dengan kata lain Teknik ini merupakan proses reproduksi dari hubungan kelamin dua organisme sejenis berbeda kelamin yang mengalami pembuahan diluar untuk mendapatkan anakan yang sama dengan induk ${ }^{7}$.

Berdasarkan permasalah di atas, apabila bioteknologi medis ini diterapkan kepada manusia akan banyak menimbulkan permasalahan etis. Namun, disisi lain perkembangan bioteknologi medis tidak dapat dipungkiri bahwa hal tersebut akan memberikan kemungkinan manusia untuk hidup lebih panjang, mengobati banyak penyakit, mendapatkan keturunan tanpa harus melalui Lembaga perkawinan dan meminimalisir kemungkinan kematian bayi saat dilahirkan. Kehadiran bioteknologi akan menguasai kehidupan manusia dan memiliki kekuatan besar untuk mengubah jalannya perkembangan organisme hidup. Orang tidak hanya menemukan dan mengurai kehidupan, tetapi berusaha mengubah dan menciptakan kehidupan. Kemajuan pesat yang terjadi di bidang bioteknologi medis membuat manusia berusaha menemukan hal baru dalam pola dan tujuan ${ }^{8}$.

Perkembangan bioteknologi dengan segala pro kontra di dalamnya menciptakan suatu kondisi yang menarik untuk dikaji serta dianalisa bila dikaitkan dengan pengelolaan produk bioteknologi medis yang aman bagi lingkungan dan sesuai dengan martabat manusia, moral, etika dan agama sehingga hasil kajian penelitian bioteknologi setidaknya diharapkan akan memiliki kriteria batas yang jelas antara teknologi dan produk berbahaya dan tidak berbahaya. Selain itu, produk-produk yang dihasilkan dari rekayasa genetika aman digunakan sesuai kegunaan serta diatur dengan perundang-undangan yang jelas agar tidak menimbulkan bias pendapat dan tidak mengabaikan martabat kemanusiaan, hukum dan HAM serta permasalahan hukum Agama.

\footnotetext{
${ }^{6}$ Veronica Komalawati, Membangun Hukum Yang Manusiawi Dalam Mencegah Eksploitasi Bioteknologi, Informasi Genetik, Dan Bioterorisme di Indonesia, Orasi Ilmiah Guru Besar Hukum Kesehatan, Fakultas Hukum Universitas Padjadjaran, Bandung, 2009, hlm 9

7 Muhammad Djumhana, 1995, hlm 58, Dalam Veronica Komalawati, Membangun Hukum....., Op Cit, hlm 8

${ }^{8}$ Arman Anwar,2010, Penerapan Bioteknologi rekayasa genetika dibidang medis ditinjau dari perspektif filsafat Pancasila, HAM dan hukum kesehatan di Indonesia, Jurnal sasi, 17(4):39-51
} 


\section{TINJAUAN PUSTAKA \\ Bioteknologi}

Bioteknologi pertama sekali diperkenalkan pada tahun 1919 oleh seorang sarjana pertanian Hongaria, Karl Ereky. Pada waktu itu, istilah ini digunakan untuk menghasilkan suatu produk dengan bantuan organisme hidup. Ereky memperkirakan bahwa krisis pangan dan energi akan dapat diselesaikan melalui bioteknologi. Bioteknologi adalah perpaduan yang harmonis antara biologi dan teknologi. Secara terminologi, bioteknologi dapat kita artikan sebagai pemanfaatan sistem biologi, makhluk hidup dan produknya untuk mengubah atau memperbaiki kesehatan umat manusia dan lingkungannya. Bioteknologi dapat definisikan sebagai aplikasi prinsip-prinsip dasar sains dan perekayasaan atas proses material dengan bantuan agen biologi untuk menghasilkan berbagai barang dan jasa. Keunggulan bioteknologi telah mengambil alih dan menjadi revolusi baru dalam ilmu biologi, melalui pengelolaan produk-produk alami menggantikan proses kimiawi dan industri. Bioteknologi merupakan ilmu dan sains masa depan yang menarik minat para ilmuwan, serta akan melahirkan suatu revolusi besar dalam kehidupan kita dengan menunjukkan bagaimana cara hidup yang lebih nyaman, bebas dari berbagai macam penyakit dan stres. ${ }^{9}$

Beberapa ilmu dan teknologi yang mendukung bioteknologi adalah sebagai berikut :

1. Mikrobiologi

Mikrobiologi merupakan cabang biologi yang mempelajari tentang mikroba atau jasad renik. Pengetahuan tentang sifat-sifat dan struktur mikroba mendukung kemajuan bioteknologi. Misalnya, mikroba berupa bakteri dapat tumbuh pada kisaran suhu tertentu. Pengetahuan mengenai bakteri ini dapat digunakan untuk membuat yoghurt, yang menggunakan bakteri Lactobacillus bulgaricus, pada kisaran suhu tertentu.

2. Biologi Sel

Biologi sel merupakan cabang biologi yang mempelajari tentang sifat-sifat dan struktur sel. Pengetahuan mengenai sifat protoplasma suatu sel yang dapat berfusi atau bergabung dengan protoplasma sel lain pada spesies yang sama maupun berbeda, bermanfaat bagi aplikasi fusi sel untuk meningkatkan keragaman hayati. Fusi sel tersebut dapat dilakukan pada sel tanaman kedelai dengan jagung, serta sel tanaman kedelai dengan kacang kapri.

3. Genetika

Genetika merupakan cabang biologi yang mempelajari pewarisan sifat-sifat genetik makhluk hidup dari suatu generasi ke generasi berikutnya. Pemahaman mengenai bentuk dan karakteristik materi pewaris sifat, yaitu DNA (gen) maupun RNA akan membantu percepatan kemajuan bioteknologi. Tanaman transgenik tomat yang tahan disimpan lama, insulin manusia yang disintesis dari bakteri Escherichia coli dan lainnya merupakan penerapan ilmu genetika dalam bioteknologi.

4. Biokimia

Biokimia merupakan cabang ilmu kimia yang mempelajari makhluk hidup dari aspek kimianya. Biokimia menganggap hidup adalah kimia, gejala hidup adalah gejala kimia dan proses-proses hidup diselenggarakan atas dasar reaksi dan peristiwa kimia. Dengan biokimia maka ahli

9 Dr. Ir. Teuku Tajuddin. 2021. Pengantar Bioteknologi. http://repository.ut.ac.id/4340/1/PEBI4426-M1.pdf [ 1 Juli 2021] 
bioteknologi memperlakukan makhluk hidup sebagai bahan kimia yang dapat dipadukan dan direkayasa.

5. Imunologi

Imunologi mempelajari semua aspek sistem imun (kekebalan tubuh) dalam merespons atau melawan mikroorganisme atau unsur asing penyebab penyakit (seperti virus, bakteri, dan racun dari bakteri), termasuk struktur dan fungsi sistem imun, kegagalan pada sistem imun, imunisasi, dan transplantasi organ tubuh.

\section{Teknologi Rekayasa Genetika}

Rekayasa genetika yang sering kali disebut dengan teknologi DNA rekombinan merupakan pemicu lahirnya bioteknologi molekuler. DNA rekombinan dikonstruksi dengan menggabungkan materi genetik dari dua atau lebih sumber yang berbeda atau melakukan perubahan secara terarah pada suatu materi genetik tertentu. Karena, materi genetik melakukan rekombinasi secara konstan.

Berikut ini merupakan beberapa contoh rekombinasi dari dua sumber atau lebih.

a. Rekombinasi yang terjadi saat pindah silang dalam pembentukan gamet pada proses meiosis.

b. Saat sperma dan ovum melebur pada proses fertilisasi.

c. Saat bakteri melakukan transaksi bahan genetik melalui konjugasi transformasi atau transduksi.

Rekombinasi merupakan salah satu cara untuk meningkatkan terjadinya keragaman hayati di alam. Materi genetik yang ada di alam menyajikan suatu bahan mentah evolusi yang dilakukan oleh seleksi alam atau seleksi buatan yang dilakukan oleh manusia.

Istilah teknologi DNA atau rekayasa genetika secara ringkas dapat diartikan sebagai teknik molekuler yang tepat dan mampu menggabungkan molekul DNA tertentu dari sumber-sumber berbeda. Rekombinasi DNA dilakukan dengan enzim (enzim restriksi dan enzim ligase) yang dapat melakukan pemotongan dan penyambungan molekul DNA dengan tepat dan dapat diperkirakan. DNA rekombinan, selanjutnya dimasukkan ke dalam makhluk sasaran dengan introduksi langsung (transformasi) melalui virus atau bakteri.

\section{Rekayasa Genetika dalam Pandangan Islam}

Kloning merupakan salah satu contoh dari rekayasa genetika yang bertaut dengan interaksi sosial. Pertautan tersebut dapat dilihat bahwa manusia sejak Nabi Adam AS sudah terdiri dari 2 (dua) jenis, yaitu laki-laki dan perempuan. Dua jenis kelamin ini menjalin hubungan (cinta kasih) sesuai dengan prinsip normatif pada masanya yang dilakukan melalui perkawinan. Lembaga perkawinan ini sangat dihormati atau diagungkan dan dari sinilah lahir martabat manusia.

Dari segi ilmu pengetahuan dan teknologi, pengaplikasian kloning pada manusia, mungkin dapat berhasil. Hal tersebut terbukti ketika para peneliti dari perusahaan Advanced Cell Technoloy (ACT), Massachusetts Amerika Serikat. Para peneliti menciptakan sel stem atau sekumpulan sel induk yang diperoleh dengan menghasilkan sel yang diambil dari bagian lengan manusia menjadi inti sel, sedangkan sel telur sapi menjadi cangkangnya. Para ilmuwan yang merekayasa kloning ini yakin keberhasilan itu merupakan langkah signifikan untuk membuat sel-sel manusia. Penemuan ini menimbulkan debat mengenai keetisan kloning manusia dan seberapa besar manfaat teknik itu untuk manusia. 
ACT dikenal sebagai perusahaan swasta yang pertamakali melakukan kloning embrio manusia dan mengembangkannya hingga 12 hari, kemudian dihancurkan. Hal ini disebabkan karena dalam keadaan normal, embrio yang menempel dinding rahim terjadi ketika bakal janin berusia 14 hari. Pihak ACT berusaha meyakinkan dunia bahwa bakal embrio itu tidak bisa dikatakan sebagai manusia karena belum berusia 14 hari. Hal tersebut diinformasikan ACT untuk menepis kekhawatiran sebagian orang terhadap kemungkinan ACT melakukan pembuahan buatan. Mereka mengatakan kepada pers tidak berminat menggunakan kloning untuk menciptakan suatu kehidupan. Perhatian mereka yang utama adalah kloning untuk keperluan terapi.

Pelaksanaan kloning yang dilakukan oleh para peneliti ACT yaitu sel telur sapi diambil dan kemudian materi genetiknya, DNA (asam deoksiribonukleat) dihilangkan untuk diganti dengan DNA manusia. Sel baru itu kemudian direkayasa secara kimiawi sehingga bisa seperti embrio baru yang kemudian mulai melakukan pembelahan sel, sebagaimana yang terjadi dalam proses pembuahan alami. Dengan cara ini, para peneliti ACT mengharapkan bisa memproduksi sel-sel induk. Para ilmuwan yang mendukung ACT malah berpendapat cepat atau lambat perkembangan teknologi akan membuat kelahiran manusia kloning tak mustahil lagi. Apalagi bila ambisi para ilmuwan Amerika yang tergabung dalam proyek Human gene merencanakan untuk merampungkan peta lengkap seluruh DNA manusia pada tahun 2003 benar-benar tercapai. Seorang ahli biologi, dari negara tersebut, Craig Venter malah lebih ambisius, yaitu akan membaca sandi seluruh gen manusia pada tahun 2001, berarti fungsi gen penyusun manusia bisa dibaca. Maka dengan penemuan tersebut, jalan untuk menciptakan manusia kloning yang sempurnapun makin terbuka. ${ }^{10}$ Cloning tersebut apabila dikaitkan dengan perkawinan, akan timbul masalah, karena kloning bisa berhasil tanpa keterlibatan jenis kelamin laki-laki, padahal menurut pandangan Islam laki-laki dan perempuan diciptakan oleh Allah sebagai pasangan untuk menjalin cinta kasih, sebagaimana firman Allah dalam Surat Ar-Ruum (30) ayat 21 :

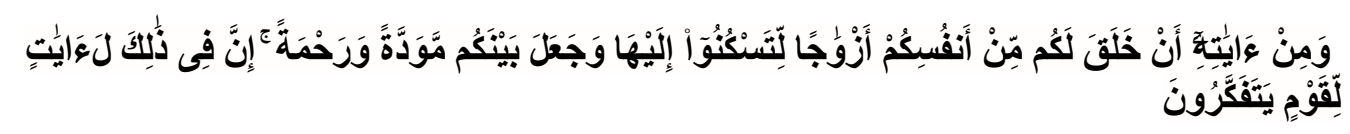

Artinya : Dan diantara tanda-tanda kekuasaan-Nya ialah Dia menciptakan untukmu istri-istri dari jenismu sendiri, supaya kamu cenderung dan merasa tentram kepadanya, dan dijadikan-Nya diantaramu rasa kasih dan sayang. Sesungguhnya pada yang demikian itu benarbenar terdapat tanda-tanda bagi kaum yang berfikir.

Menghasilkan anak tanpa melalui hubungan suami istri yang sah, diperkirakan disini terdapat masalah hukum yang amat prinsipal, karena mulai merusak lembaga perkawinan. Hal ini disebabkan dalam perkawinan terdapat perikatan yang menuntut adanya dua pihak yang mengikatkan diri pada hubungan normatif. Kekuatan mengikatkan diri tersebut berpotensi sebagai "mitsaqon ghalidha".

Pada proses kloning potensi tersebut tidak akan mungkin ditemukan, bahkan cenderung menyuguhkan suatu hubungan dipaksakan oleh pelaku kloning pada pemilik inti sel dengan diri pemilik itu sendiri yang bebas dari ikatan

\footnotetext{
${ }^{10}$ Tempo, 1 Agustus 1999, hal. 48
} 
hubungan normatif. Apabila inti sel ditanamkan pada rahim perempuan lain, disini akan menimbulkan masalah, yaitu siapa ibu anak tersebut, apakah yang mengandung serta melahirkannya atau yang memberi inti sel. Biarpun begitu, AlQur'an memberi gambaran tentang soal ini, bahwa ibu anak tersebut lebih cenderung ibu yang melahirkannya, hal ini dapat disimpulkan dari firman Allah Surat Al-Mujaadilah (58) ayat 2 :

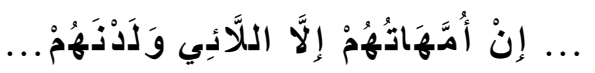

Artinya : “... Ibu-ibu mereka tidak lain hanyalah wanita yang melahirkan mereka ...”.

Pada kasus-kasus di atas, mungkin akan terjadi perselisihan tentang hak anak antara kedua perempuan tersebut jika sebelumnya tidak terdapat perjanjian yang mengikat. Walaupun terdapat perjanjian bahwa pemilik inti sel berhak pada anak tersebut, tetap saja bukan anak kandungnya, tetapi harus melalui proses pengangkatan anak, sedangkan menurut Al-Qur'an bahwa anak angkat tidak sama dengan anak kandung, hal ini dapat diketahui dari firman Allah Surat Al-Ahzab (33) ayat 4 :

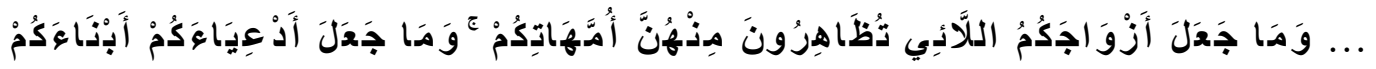

Artinya : “... Dan Dia tidak menjadikan anak-anak angkatmu sebagai anak kandungmu...”.

Bila status anak tersebut sebagai anak angkat dari pemilik inti sel telur, maka masalah selanjutnya bila ibu tersebut meninggal dunia, konsekwensinya anak itu tidak bisa menjadi ahli warisnya dan otomatis terhalang untuk menerima harta warisan dari ibunya tersebut, walaupun pada waktu ibunya masih hidup dibolehkan memberikan hibah kepadanya.

Timbul masalah lagi apabila anak tersebut telah menginjak mendekati dewasa dan dia mengetahui bahwa ibu bapaknya yang mengangkat selama ini bukan ibu bapak asli, kemudian dia bertanya siapa ibu serta bapak yang sebenarnya, pertanyaan tersebut tentu sulit dijawab. Keadaan tersebut tentu akan menyebabkan beban psikologis tersendiri baginya. Selanjutnya apabila anak tersebut, kebetulan wanita dan sudah menjadi dewasa serta akan menikah, ibu angkatnya (sekalipun pemilik inti sel telur) dalam sistem hukum Islam tidak diperbolehkan menjadi wali nikah, karena wali nikah pada sistem hukum Islam diambil dari garis laki-laki, misalnya bapak, kakek, paman dan lain-lain, padahal wali nikah bagi gadis yang akan menikah sangat penting, bahkan Nabi Muhammad SAW. dalam salah satu riwayat bersabda: Perempuan yang menikah tanpa ijin dari walinya, maka nikahnya batal (Hadits Riwayat Bukhori dan Muslim).

Kaitan dengan ilmu dan teknologi, agama Islam sesungguhnya sangat mendorong kaum muslimin agar mau menguasai dan memanfaatkan iptek dengan sebaik-baiknya. Disamping itu, agama Islam mendorong juga agar pemanfaatannya menghormati manusia dan bukan menghancurkannya. Oleh 
karena itu, agama Islam membimbing para ilmuwan muslim bagaimana sebaiknya pengembangan ilmu dan teknologi menurut ajaran Islam, yaitu sebagai berikut ${ }^{11}$ :

1. Islam tidak mengenal kompartementalisasi bidang-bidang kehidupan manusia, sehingga bidang pengembangan ilmu dan teknologi juga merupakan bagian integral kehidupan seorang muslim secara utuh. Oleh karena itu kedua bidang tersebut dan seluruh kehidupan muslim lainnya terpadu dalam kehidupan tauhid.

2. Seluruh kehidupan muslim, termasuk dalam mengembangkan ilmu dan teknologi, pada hakikatnya dalam rangka mengabdi kepada Allah SWT. AlQur'an mengajarkan bahwa seluruh kegiatan seorang muslim hanya dipersembahkan kepada Allah semata, sebagaimana firman Allah dalam Surat Al-An'am (6) ayat 162 :

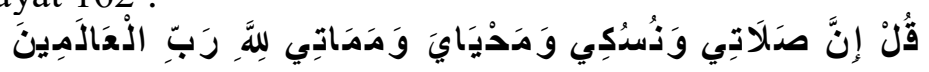

Artinya : Katakanlah: Sesungguhnya shalatku, ibadatku, hidupku dan matiku hanyalah untuk Allah, Tuhan semesta Alam.

3. Ilmu dan teknologi yang dikembangkan oleh para sarjana muslim adalah yang membawa rahmat bagi seluruh umat manusia, bukan yang membawa laknat. Kedua bidang tersebut dalam pandangan Islam adalah sarat nilai, tidak netral dan bukannya tanpa kendali. Keduanya harus dikembangkan bagi kebahagiaan umat manusia dan kelestarian ekologi. Hal ini sesuai dengan firman Allah dalam Surat Al-Anbiya (21) ayat 107 dan Surat ArRuum (30) ayat 41, yang artinya : Dan tidaklah kami mengutus kamu, melainkan untuk (menjadi) rahmat bagi seluruh alam (Al-anbiya (21) ayat 107); Telah nampak kerusakan di darat dan di laut disebabkan karena perbuatan manusia, supaya Allah merasakan kepada mereka sebagian dari (akibat) perbuatan mereka, agar mereka kembali (ke jalan yang benar) (ArRuum (30) ayat 41).

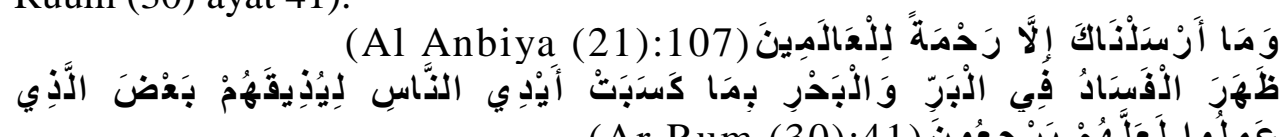

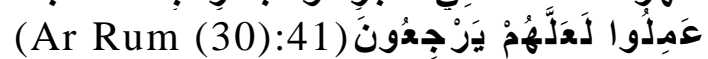

4. Ilmu dan teknologi boleh dikembangkan sejauh mungkin selama berlandaskan alakhlaqul karimah. Keridoan Allah sebagai jiwa dari moral ilmu dan teknologi, memberikan arah yang cukup jelas. Dalam hal ini, hubungan manusia dengan Allah, dengan sesama manusia dan hubungan manusia dengan alam, dalam pandangan Islam merupakan hubungan yang serasi. Jadi disekuilibrium antara manusia dan alam harus dihindarkan. Berkaitan dengan hal ini, Rasulullah SAW bersabda :

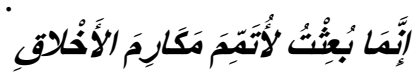

Artinya: Hanya saja Aku diutus untuk menyempurnakan akhlak yang mulia.

5. Harus terdapat korelasi positif antara pengembangan ilmu dan teknologi dengan peningkatan takwa kepada Allah SWT. Dengan ditemukannya rahasia alam semesta dan hukum-hukumnya yang teratur, maka ilmu dan teknologi selayaknya berfungsi meningkatkan rasa takwa para pengembangnya dalam rangka mengabdi kepada Allah SWT. Dengan demikian, para ilmuwan muslim akan terhindar dari kecongkakan intelektual yang kadang-kadang menghinggapi cendikiawancendikiawan non muslim. Hal ini dapat dilihat dalam Al-Qur'an Surat Fushilat (41) ayat 53 :

${ }^{11}$ M.Amin Rais. 1987. Pengembangan Ilmu dan Teknologi dalam Islam, dalam Cakrawala Islam antara Cita dan Fakta. Bandung: Mizan. hal. 114 -115. 


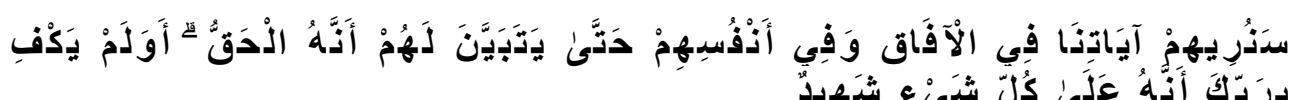

Artinya : Kami akan memperlihatkan kepada mereka tanda-tanda (kekuasaan) Kami di segenap ufuk dan pada diri mereka sendiri, sehingga jelaslah bagi mereka bahwa Al-Qur'an itu adalah benar. Dan apakah Tuhanmu tidak cukup (bagi kamu) bahwa sesungguhnya Dia menyaksikan segala sesuatu ${ }^{12}$

\section{METODE PENELITIAN}

Metode penelitian yang digunakan untuk mengetahui tingkat pengetahuan mahasiswa Biologi mengenai penerapan bioteknologi rekayasa genetika dalam perspektif Islam dilakukan menggunakan tiga evaluasi, yaitu perencanaan (antecedents), proses (transactions), dan hasil (outcomes). Penelitian yang dilakukan oleh peneliti menggunakan penelitian evaluasi dengan pendekatan mix methods (campuran). Peneliti menggunakan pendekatan mix methods agar diperoleh data dan analisa yang mendalam terhadap penelitian evaluasi, baik dari data kualitatif maupun data kuantitatif.

Penelitian dilakukan dengan cara mengumpulkan data mengenai apa yang diinginkan pengembang program baik yang berhubungan dengan perencanaan (antecedents) yang berupa pengumpulan artikel dan jurnal terkait bioteknologi rekayasa genetika melalui studi literatur, kemudian peneliti mengumpulkan data dari komponen proses berupa pemberian kuisioner, strategi pendukung dan materi atau isi pembelajaran yang dilakukan dan langkah terakhir pengumpulan data dari hasil yang meliputi perkembangan pengetahuan dan perkembangan sikap dan data-data diperoleh melalui studi dokumen.

\section{HASIL DAN PEMBAHASAN}

Rekayasa genetika khususnya dalam tekning kloning merupakan sesuatu yang awam di tengah mahasiswa Biologi. Diperlukan pemahaman mengenai rekayasa genetika kepada mahasiswa Biologi agar mahasiswa Biologi mengetahui batasan-batasan hukum Islam dalam pelaksanaan bioteknologi rekayasa genetika. Rekayasa genetika dilakukan dengan cara penggabungan material genetik dari dua atau lebih sumber yang berbeda untuk melakukan perubahan secara terarah pada suatu materi genetik tertentu. Penelitian diawali dengan perencanaan berupa pengumpulan artikel berupa jurnal maupun berita terkait bioteknologi rekayasa genetika. Kemudian, peneliti meminta 60 mahasiswa biologi di universitas X \& Y untuk memaparkan pengetahuan bioteknologi rekayasa genetika dari setiap mahasiswa. Selanjutnya peneliti menanyakan pengetahuan mahasiswa terkait bioteknologi rekayasa genetika dalam perspektif Islam. Hasil pengamatan yang dilakukan mengenai pesan teks WhatsApp (WA) dikaji lebih lanjut, kemudian peneliti memberikan pengetahuan mengenai bioteknologi rekayasa genetika dalam perspektif Islam berdasarkan artikel, jurnal dan berita terkait yang sudah dikumpulkan. Selanjutnya, peneliti memberikan waktu kepada mahasiswa untuk mempelajari artikel terkait dan mengumpulkan pendapat mahasiswa mengenai boleh/tidaknya pelaksanaan bioteknologi rekayasa genetika dalam perspektif Islam (tabel 1).

12 Tata Fathurrohman. Kloning menurut pandangan Islam. Hal 44-54. https://media.neliti.com/media/publications/7482-ID-kloning-menurut-pandangan-islam.pdf [1 Juli 2021] 
Table 1 Metode Penelitian Pengetahuan Mahasiswa mengenai penerapan Bioteknologi Rekayasa Genetika

\begin{tabular}{ll}
\hline No & Kegiatan \\
\hline 1 & Pengumpulan Artikel, Jurnal dan Berita \\
2 & Pemaparan Pengetahuan dan Pengajuan pertanyaan \\
3 & Sesi Diskusi \\
4 & Ulasan pernyataan, Pelurusan pembahsan/pernyataan \\
5 & Voting pendapat mengenai boleh / tidaknya bioteknologi rekayasa \\
6 & Oenetika \\
\hline
\end{tabular}

Hasil penelitian pada tabel 2 menunjukkan, 27 mahasiswa biologi dari Universitas $\mathrm{X}$ dan 18 mahasiswa biologi dari Universitas $\mathrm{Y}$ hanya memahami pembelajaran bioteknologi rekayasa genetika dalam konteks umum sehingga mahasiswa kurang pemahaman dari segi Agama. Sedangkan, sisanya memiliki pemahaman bioteknologi rekayasa genetika dalam perspektif Islam dan Umum. Data tersebut digunakan sebagai data acuan peneliti sebelum memberikan artikel terkait yang berkaitan dengan perspektif Islam. Selanjutnya, peneliti memberikan artikel terkait bioteknologi rekayasa genetika untuk dipelajari dan dipahami. Peneliti memberikan waktu kepada mahasiswa untuk mempelajari artikel tersebut dan membuka sesi diskusi melalui WA selama seminggu. Hasil sesi diskusi pada setiap mahasiswa menunjukkan peningkatan dan antusiasme mahasiswa untuk mempelajari ilmu biologi khususnya bioteknologi rekayasa genetika jika dipelajari dalam perspektif Islam. Sesi diskusi menunjukan bahwa, jika ilmu biologi yang dipelajari di kampus sebagai ilmu umum akan terasa kurang lengkap jika tidak dilengkapi dengan pemahaman dari segi Agama. Pemahaman ilmu bioteknologi rekayasa genetika dalam perspektif Islam memberikan pengetahuan baru bagi 45 mahasiswa bahwa dalam pelaksanaan bioteknologi rekayasa genetika memerlukan acuan yang telah ditetapkan dalam Al Qur'an, Hadits, pendapat ulama serta fatwa-fatwa MUI.

Table 2 Hasil Pengamatan

\begin{tabular}{llll}
\hline No & Keterangan & Mahasiswa X & Mahasiswa Y \\
\hline 1 & Jumlah Mahasiswa & 35 Mahasiswa & 25 Mahasiswa \\
2 & $\begin{array}{l}\text { Pengetahuan Rekayasa Genetika dalam } \\
\text { perspektif Islam (sebelum pembagian }\end{array}$ & 8 Mahasiswa & 7 Mahasiswa \\
artikel terkait melalui WA) & & \\
3 & $\begin{array}{l}\text { Pengetahuan Rekayasa Genetika dalam } \\
\text { perspektif Islam (setelah pembagian }\end{array}$ & 35 Mahasiswa & 25 Mahasiswa \\
artikel terkait melalui WA) & $\begin{array}{l}\text { Voting mengenai pelaksaan rekayasa } \\
\text { genetika dari perspektif Islam }\end{array}$ & & \\
Setuju & 35 Mahasiswa & 25 Mahasiswa \\
Tidak Setuju & - & -
\end{tabular}


Rekayasa genetika sebenarnya sudah dipraktikan di zaman Nabi Muhammad SAW dengan konsep sederhana, dimana dalam Riwayat Anas bin Malik RA, Rasulullah SAW pernah berdiskusi dengan sekelompok sahabat yang melakukan pembenihan bibit kurma. Rasulullah SAW bersabda:

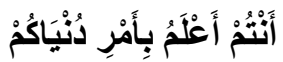

"Kalian lebih tahu tentang urusan dunia kalian." (HR Muslim, Ibnu Khuzaimah, dan Ibnu Hibban).

Hadis ini menjadi dalil pembolehan bagi kaum intelektual untuk bereksplorasi dan menemukan model pembibitan yang lebih baik. Soal urusan duniawi, tidak ada larangan untuk membuat konsep baru. Sedangkan, jika dikaitkan dengan urusan akidah dan ibadah, hal ini dikategorikan sebagai bid'ah. Bid'ah sendiri merupakan perbuatan atau pelaksaan sesuatu kegiatan yang belum pernah dilakukan pada zaman Nabi Muhammad SAW ${ }^{13}$.

Adapun sekelompok pihak yang mengatakan rekayasa genetika adalah haram karena meniru atau mengubah ciptaan Allah SWT sebenarnya telah dipatahkan dengan kaidah fikih al-aslu fil asya'a al-ibahah (hukum asal segala sesuatu adalah boleh). Kaidah tersebut merupakan salah satu kaidah fiqih yang dipegang oleh jumhur ulama dan termasuk kalangan Syafi'iyyah yang mengartikan bahwa "Hukum asal dari segala sesuatu adalah mubah". Maksudnya ialah jika sesuatu tidak ada penjelasannya yang tegas dalam nash syariat mengenai halal haram maka hukumnya ialah halal ${ }^{14}$.

Selain itu, beberapa kalangan ada juga yang tidak setuju dengan teori rekayasa genetika yang diperkenalkan Charles Darwin dalam bukunya yang berjudul "The Origin of Species". Buku tersebut menyajikan kasus yang meyakinkan tentang evolusi dan telah dapat menghubungkan apa yang sebelumnya dilihat sebagai suatu kumpulan fakta membingungkan dan tidak saling berkaitan menjadi suatu pandangan kohesif mengenai kehidupan. Buku The Origin of Species dianggap sebagai buku yang bersifat radikal untuk masa itu. Pandangan Darwin ini bukan hanya menantang pandangan ilmiah yang berlaku saat itu, tetapi juga mengguncang akar paling dalam dari kebudayaan barat ${ }^{15}$.

Sedangkan, Fatwa tentang rekayasa genetika dan produknya juga termuat dalam ketentuan umum pertama dalam fatwa MUI No.35 tahun 2013 yang menjelaskan bahwa ${ }^{16}$ :

1. Gen atau DNA (Deoxyribose Nucleic Acid) adalah Substansi pembawa sifat menurun dari sel ke sel, dan generasi ke generasi, yang terletak di dalam kromosom, yang memiliki sifat antara lain sebagai materi tersendiri yang terdapat dalam kromosom, mengandung informasi genetika, dapat menentukan sifat-sifat dari suatu individu, dan dapat menduplikasi diri pada peristiwa pembelahan sel.

${ }^{13}$ Drs. H. Mughni Labib, MSI. 2015. BID’AH. http://cilacap.kemenag.go.id/fiqh/read/bidah [15 Juni 2021]

14 Muhammad Abduh Negara. 2020. Kaidah “Al- Ashlu Fil Asy-yaa-I Al-Ibahah". https://alwaraqat.id/kaidah-al-ashlu-fil-asy-yaa-i-al-ibahah/ [15 Juni 2021]

15 Drs. Rusna Ristana, A. Sejarah Perkembangan Teori Evolusi Makhluk Hidup. Modul 1.Evolusi dan Sistematika Makhluk Hidup. 1-77

${ }^{16}$ Fatwa MUI Nomor 35 Tahun 2013. Rekayasa Genetika dan produknya. http://mui.or.id/wpcontent/uploads/files/fatwa/No.-35-Rekayasa-Genetika-dan-Produknya.pdf [15 Juni 2021] 
2. Rekayasa Genetika adalah penerapan genetika untuk kepentingan manusia, yakni penerapan teknik-teknik biologi molekular untuk mengubah susunan genetik dalam kromosom atau mengubah sistem ekspresi genetik yang pada kemanfaatan tertentu, yang obyeknya mencakup hampir semua golongan organisme, mulai dari bakteri, fungi, hewan tingkat rendah, hewan tingkat tinggi, hingga tumbuh-tumbuhan.

Selain itu, dalam ketentuan hukum juga dijelaskan mengenai :

1. Melakukan rekayasa genetika terhadap hewan, tumbuh-tumbuhan dan mikroba (jasad renik) adalah mubah (boleh), dengan syarat :

a. dilakukan untuk kemaslahatan (bermanfaat);

b. tidak membahayakan (tidak menimbulkan mudharat), baik pada manusia maupun lingkungan; dan

c. tidak menggunakan gen atau bagian lain yang berasal dari tubuh manusia.

2. Tumbuh-tumbuhan hasil rekayasa genetika adalah halal dan boleh digunakan, dengan syarat :
a. bermanfaat; dan
b. tidak membahayakan

3. Hewan hasil rekayasa genetika adalah halal, dengan syarat :

a. Hewannya termasuk dalam kategori ma'kul al-lahm (jenis hewan yang dagingnya halal dikonsumsi)

b. bermanfaat; dan

c. tidak membahayakan

4. Produk hasil rekayasa genetika pada produk pangan, obat-obatan, dan kosmetika adalah halal dengan syarat :

a. bermanfaat

b. tidak membahayakan; dan

c. sumber asal gen pada produk rekayasa genetika bukan berasal dari yang haram.

Ketentuan-ketentuan di atas yang sudah ditetapkan sesuai ketentuan sekiranya dapat mengalami perubahan dikemudian hari yang diakibatkan oleh perubahan hasil penelitian. Hasil penelitian akan terus mengalami perubahan atau pembaruan lebih baik seiring dengan perkembangan IPTEK untuk kesempurnaan produk yang dihasilkan demi kemaslahatan bersama.

Saat ini, beberapa ilmuwan telah mampu merekayasa genetika dengan mengubah susunan genetik dalam kromosom untuk mengubah ekspresi genetiknya. Hal tersebut bertujuan untuk menciptakan sesuatu sesuai dengan apa yang diinginkan oleh manusia. Rekayasa genetika pada dasarnya boleh dilakukan asal sesuai dengan ketentuan dan ketetapan Allah SWT. Banyak ilmuwan yang melakukan penelitian dengan merekayasa genetika terhadap tumbuhan, hewan dan mikroba. Sedangkan, untuk rekayasa genetika terhadap manusia masih menjadi perdebatan. Jika tujuannya untuk mendapatkan manfaat demi kemaslahatan dan tidak bertentangan dengan hukum Islam maka hukumnya diperbolehkan.

Beberapa contoh rekayasa genetika terhadap manusia ialah proses bayi tabung (inseminasi) dan kloning terhadap manusia. Sebelumnya, kloning sudah dilakukan terhadap hewan dan tidak dapat dipungkiri hal tersebut dapat dilakukan terhadap manusia. Namun, proses kloning dalam Islam masih menjadi perdebatan, karena kloning dianggap sebagai bentuk peniruan dan dianggap sebagai perbuatan 
yang melampaui batas ketentuan Allah $\mathrm{SWT}^{17}$. Ayat yang berkaitan dengan kloning dalam pandangan Islam terdapat dalam QS. Al Hajj:5 :

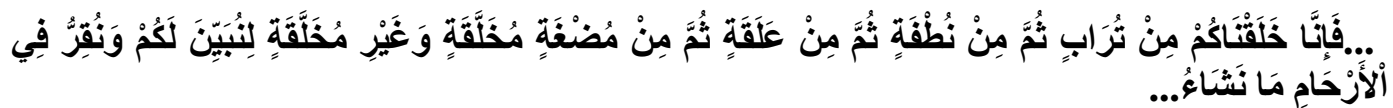

"... Kami telah menjadikan kamu dari tanah, kemudian dari setetes mani, kemudian dari segumpal darah, kemudian dari segumpal daging yang sempurna kejadiannya dan yang tidak sempurna, agar Kami jelaskan kepada kamu dan Kami tetapkan dalam rahim, apa yang Kami kehendaki ..." (QS. 22/al-Hajj: 5).

Kutipan ayat di atas menegaskan paradigma Al Quran tentang penciptaan manusia mencegah Tindakan-tindakan yang mengarah pada kloning. Karena, sesungguhnya awal kehidupan hingga kematian merupakan kuasa Allah SWT. Selain kutipan ayat di atas, terdapat surah Ali Imran yang juga dijadikan landangan persoalan berkaitan dengan kloning manusia :

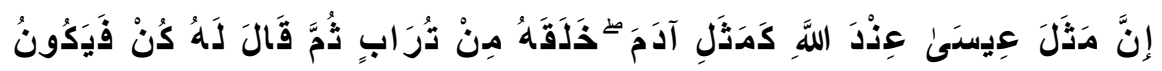

"Sesungguhnya misal (penciptaan) 'Isa di sisi Allah, adalah seperti (penciptaan) Adam. Allah menciptakan Adam dari tanah, kemudian Allah berfirman kepadanya: "Jadilah" (seorang manusia), maka jadilah dia" (QS. 3/Ali 'Imran: 59).

Kedua ayat di atas jika dikaji lebih lanjut mengenai kloning dapat dipahami bahwa kloning termasuk ke dalam kehendak atau takdir Allah yang dikuasai manusia sehingga kloning diperbolehkan dengan catatan sel somatis dan sel telur yang digunakan belum dibuahi sehingga hal tersebut tidak menyalahi agama. Terdapat beberapa ulama yang memperbolehkan dilakukannya kloning salah satunya ialah Syekh Muhammad Husein Fadhlullah, pimpinan spiritual Islam di Lebanon. Beliau mengatakan bahwa kloning terhadap manusia hukumnya halal, karena kloning bukan berarti manusia ikut campur terhadap ciptaan Tuhan dan kloning tidak serta merta mengaitkan kedudukan Tuhan. Ilmuwan tetaplah manusia dan ciptaan Tuhan ${ }^{18}$.

Syekh Muhammad Husein Fadhlullah tidak sendiri, beberapa tokoh Islam masih menganggap bahwasannya kloning manusia sebagai persoalan khilafiyyah. Perbedaan pendapat yang terjadi merupakan sebuah bukti sifat kemajemukan umat Islam dalam mengatasi sebuah permasalahan. Alasan ulama memperbolehkan melakukan kloning sebagai berikut:

a. Dalam Islam, kita selalu diajarkan untuk menggunakan akal dalam memahami agama.

b. Islam menganjurkan agar kita menuntut ilmu (dalam hadits dinyatakan bahkan sampai ke negri Cina sekalipun).

\footnotetext{
${ }^{17}$ Kompasiana. 2018. Menyoal Pandangan Islam terhadap rekayasa genetika, kloning manusia dan bayi tabung. https://www.kompasiana.com/rizkycho/5c22cf70ab12ae5f344d7358/menyoalpandangan-islam-terhadap-rekayasa-genetika-kloning-manusia-dan-bayitabung?page=all\#sectionall [ 15 Juni 2021]

${ }^{18}$ MA Shodikin. 2010. Analisis hukum Islam terhadap kloning karena infertilisasi istri [thesis]. Surabaya : UIN Sunan Ampel Surabaya
} 
c. Islam menyampaikan bahwa Allah selalu mengajari dengan ilmu yang belum ia ketahui (lihat QS. 96/al-'Alaq).

d. Allah menyatakan, bahwa manusia tidak akan menguasai ilmu tanpa seizin Allah (lihat ayat Kursi pada QS. 2/al-Baqarah: 255).

Kita menyadari bahwa penemuan teknologi bayi tabung, rekayasa genetika, dan kemudian kloning adalah juga bagian dari takdir (kehendak) Ilahi, dan dikuasai manusia dengan seizin-Nya. Penolakan terhadap kemajuan teknologi itu justru bertentangan dengan prinsip-prinsip yang diajarkan dalam Islam. Oleh karena itu, sejatinya kemajuan IPTEK yang terjadi dari masa ke masa harus diiringi dengan pemikiran terbuka dan pemahaman agama yang kuat sehingga tidak akan mengurangi keimanan serta tidak akan menimbulkan kesalahan persepsi yang menjurus ke hal-hal negatif.

Berdasarkan pemaparan yang dilengkapi dengan kutipan ayat yang berkaitan dengan bioteknologi rekayasa genetika khususnya Teknik kloning memberikan pemahaman bahwa Teknik kloning diperbolehkan dengan syarat sesuai dengan ketentuan serta aturan-aturan yang sudah dijelaskan. Dengan begitu, mahasiswa biologi Universitas $\mathrm{X}$ dan $\mathrm{Y}$ tidak hanya mempelajari ilmu biologi dari pengetahuan umum saja, melainkan mahasiswa tersebut dapat memahami ilmu biologi berdasarkan pengetahuan umum dan perspektif Islam sehingga dalam pelaksanaan bioteknologi rekayasa genetika tidak akan menggunakan bahan, alat, Teknik kerja serta produk yang tidak sesuai dengan hukum-hukum Islam.

\section{KESIMPULAN}

Rekayasa genetika merupakan bentuk kemajuan IPTEK dalam bidang bioteknologi medis. Kloning merupakan salah satu contoh rekayasa genetika dimana pelaksanaannya banyak menimbulkan pro kontra. Beberapa pendapat melarang pelaksanaan kloning dikarenakan kloning dianggap bertentangan dengan hukum Islam sehingga tidak diperbolehkan. Berbeda halnya dengan pendapat Syekh Muhammad Husein Fadhlullah yang mengatakan bahwa kloning terhadap manusia hukumnya halal. Kloning dianggap sesuatu yang tidak ada kaitannya dengan ikut campurnya manusia terhadap ciptaan Tuhan. Selain itu, kloning tidak serta merta mengaitkan kedudukan Tuhan, karena ilmuwan tetaplah manusia dan ciptaan Tuhan. Oleh karena itu, kemajuan IPTEK khususnya dalam rekayasa genetika harus diiringi dengan pemikiran terbuka dan pemahaman agama yang kuat agar tidak menimbulkan kesalahan persepsi ke hal negatif.

Berkaitan dengan hasil penelitian yang dilakukan adalah diperlukannnya pengawasan hukum Islam yang ketat dan sanksi yang tegas berkaitan dengan penelitian rekayasa genetika khususnya kloning. Selain itu, Indonesia diharapkan selalu aktif dan ikut berpartisipasi dalam konferensi mengenai perkembangan bioteknologi maupun lingkungan agar perkembangan tersebut dapat dilakukan kajian dengan MUI mengenai larangan atau hal yang boleh dilakukan dalam melakukan penelitian serta diperlukannya badan khusus berbasis kajian Islam terkait perkembangan bioteknologi di Indonesia. 


\section{DAFTAR PUSTAKA}

Arman Anwar,2010, Penerapan Bioteknologi rekayasa genetika dibidang medis ditinjau dari perspektif filsafat Pancasila, HAM dan hukum kesehatan di Indonesia, Jurnal sasi, 17(4):39-51

Dr. Ir. Teuku Tajuddin. 2021. Pengantar Bioteknologi. http://repository.ut.ac.id/4340/1/PEBI4426-M1.pdf [ 1 Juli 2021]

Drs. H. Mughni Labib, MSI. 2015. BID'AH. http://cilacap.kemenag.go.id/fiqh/read/bidah [15 Juni 2021]

Drs. Rusna Ristana, A. Sejarah Perkembangan Teori Evolusi Makhluk Hidup. Modul 1.Evolusi dan Sistematika Makhluk Hidup. 1-77

Fatwa MUI Nomor 35 Tahun 2013. Rekayasa Genetika dan produknya. http://mui.or.id/wp-content/uploads/files/fatwa/No.-35-RekayasaGenetika-dan-Produknya.pdf [15 Juni 2021]

Kompasiana. 2018. Menyoal Pandangan Islam terhadap rekayasa genetika, kloning manusia dan bayi tabung. https://www.kompasiana.com/rizkycho/5c22cf70ab12ae5f344d7358/meny oal-pandangan-islam-terhadap-rekayasa-genetika-kloning-manusia-danbayi-tabung?page=all\#sectionall [ 15 Juni 2021]

MA Shodikin. 2010. Analisis hukum Islam terhadap kloning karena infertilisasi istri [thesis]. Surabaya : UIN Sunan Ampel Surabaya

M.Amin Rais. 1987. Pengembangan Ilmu dan Teknologi dalam Islam, dalam Cakrawala Islam antara Cita dan Fakta. Bandung: Mizan. hal. 114 -115.

Muhammad Abduh Negara. 2020. Kaidah "Al- Ashlu Fil Asy-yaa-I Al-Ibahah". https://alwaraqat.id/kaidah-al-ashlu-fil-asy-yaa-i-al-ibahah/ [15 Juni 2021]

Muhammad Djumhana, 1995, hlm 58, Dalam Veronica Komalawati, Membangun Hukum....., Op Cit, hlm 8

Onong Uchjana Effendy, Ilmu Komunikasi Teori dan Filsafat Komunikasi (Bandung, PT. Cipta Aditya Bakti, 2000), h.9

Pedoman Etik Indonesia, 1987: hlm5-12, dalam Veronica Komalawati, Peranan Informed....,Op Cit hlm 89-90

Ratna Suprapti Samil, Etika Kedokteran Indonesia, Yayasan Bina Pustaka Sarwono Prawirohardjo, Jakarta, 2001, hlm 121

Tata Fathurrohman. Kloning menurut pandangan Islam. Hal 44-54. https://media.neliti.com/media/publications/7482-ID-kloning-menurutpandangan-islam.pdf [1 Juli 2021]

Tempo, 1 Agustus 1999, hal. 48

Veronica Komalawati, Membangun Hukum Yang Manusiawi Dalam Mencegah Eksploitasi Bioteknologi, Informasi Genetik, Dan Bioterorisme di Indonesia, Orasi Ilmiah Guru Besar Hukum Kesehatan, Fakultas Hukum Universitas Padjadjaran, Bandung, 2009, hlm 9

Veronica Komalawati, Peranan Informed Consent Dalam Transaksi Terapeutik Suatu Tinjauan Yuridis Persetujuan Dalam Hubungan Dokter dan Pasien, Citra Aditya Bakti, Bandung, 1999, hlm 89-90.

Wijaya, dkk, Komunikasi Terapeutik (Bandung: Akademi Kesehatan Gigi Depkes RI, 2000), h.34 